\title{
Magnetic resonance imaging features of Familial Mediterranean Fever associated spondyloarthritis
}

\author{
A Turan', R Mercan², B Bitik², H Kucuk², MA Ozturk², A Tufan²* \\ From 8th International Congress of Familial Mediterranean Fever and Systemic Autoinflammatory Diseases \\ Dresden, Germany. 30 September - 3 October 2015
}

\section{Background}

Inflammatory back pain is a frequent complaint among Familial Mediterranean Fever (FMF) patients and spondyloarthritis is a well-known chronic manifestation of disease affecting about $10 \%$ of patients. However, literature is lacking for a systematic study investigating radiologic features of this particular patient group.

\section{Objectives}

To determine Magnetic Resonance Imaging (MRI) characteristics of patients with FMF associated spondyloarthritis (FMF-SPA).

\section{Methods}

Twenty-nine patients followed up in our clinic with FMF-SPA who fulfilled ASAS classification criteria for axial spondyloarthritis. To figure out only characteristics of FMF-SPA, we excluded those patients with psoriasis, Crohn disease/ulcerative colitis or positive HLA-B27 tests. Patient demographics, clinical features and MEFV mutation analyzes were recorded. All patients underwent sacroiliac and spinal contrast enhanced MR examination. T1, T2 weighted images (WI), STIR sequence and post-contrast fat saturated T1 WI were used to define MRI features.

\section{Results}

The mean (min-max) age of patients was $32.8 \pm 7.7$ (19-53) years and 55.2\% were female. Age at the onset of the inflammatory back pain was $20.5 \pm 5.5(10-30)$ years and age at the diagnosis was $29 \pm 5.4(22-35)$. The duration of symptoms was $11.9 \pm 8.6(1-28)$ years at the time of MR examination. M694V mutation was the most commonly observed MEFV mutation in FMF-SPA patients (75.9\%). In sacroiliac joint, active lesions were

${ }^{2}$ Gazi University, Rheumatology, Ankara, Turkey

Full list of author information is available at the end of the article evident in 19 patients and sacroiliac joint involvement was bilateral in 20 of them. Spinal lesions were quite rare. The most common finding in the axial skeleton was facet joint arthritis.

\section{Conclusions}

Our results confirmed the role of M694V on risk of spondyloarthritis development in patients with FMF. Unlike ankylosing spondylitis, spinal chronic lesions were quite uncommon, even those patients with substantial disease duration and severe sacroiliac joint involvement. Therefore, these results suggest that FMF-SPA might be a distinct type in spondyloarthropathy spectrum of diseases.

\section{Authors' details}

${ }^{1}$ Yildirim Beyazit T\&R Hospital, Radiology, Ankara, Turkey. ${ }^{2}$ Gazi University, Rheumatology, Ankara, Turkey.

Published: 28 September 2015

doi:10.1186/1546-0096-13-S1-P114

Cite this article as: Turan et al:: Magnetic resonance imaging features of Familial Mediterranean Fever associated spondyloarthritis. Pediatric Rheumatology 2015 13(Suppl 1):P114.

Submit your next manuscript to BioMed Central and take full advantage of:

- Convenient online submission

- Thorough peer review

- No space constraints or color figure charges

- Immediate publication on acceptance

- Inclusion in PubMed, CAS, Scopus and Google Scholar

- Research which is freely available for redistribution 